Georgia State University

ScholarWorks @ Georgia State University

$1-4-2013$

\title{
Employee Voice before Hirschman: Its Early History, Conceptualization, and Practice
}

Bruce E. Kaufman

Georgia State University, bkaufman@gsu.edu

Follow this and additional works at: https://scholarworks.gsu.edu/uwrg_workingpapers

\section{Recommended Citation}

Kaufman, Bruce E., "Employee Voice before Hirschman: Its Early History, Conceptualization, and Practice" (2013). UWRG Working Papers. 68.

https://scholarworks.gsu.edu/uwrg_workingpapers/68

This Article is brought to you for free and open access by the Usery Workplace Research Group at ScholarWorks @ Georgia State University. It has been accepted for inclusion in UWRG Working Papers by an authorized administrator of ScholarWorks @ Georgia State University. For more information, please contact scholarworks@gsu.edu. 
Working Paper 2013-1-4 January 2013

\section{Employee Voice before Hirschman: Its Early History, Conceptualization, and Practice}

Bruce E. Kaufman

Georgia State University

\section{ANDREW Young SchoOL}


Employee Voice before Hirschman: Its Early History, Conceptualization, and Practice*

Bruce E. Kaufman**

January 28, 2013

*Chapter for Adrian Wilkinson, Jimmy Donaghey, Tony Dundon, and Richard Freeman (eds.), The Handbook of Research on Employee Voice (Elgar, forthcoming).

** Bruce E. Kaufman (bkaufman@gsu.edu) is a Professor in the Department of Economics, Andrew Young School of Policy Studies, and an associate of the W.J. Usery Center for the Workplace at Georgia State University. He is also affiliated with the Centre for Work, Organization and Wellbeing and the Department of Employment Relations and Human Resources at Griffith University in Brisbane, Australia, and the Work and Employment Research Unit at Business School of the University of Hertfordshire in Hatfield, United Kingdom. 
Employee Voice before Hirschman: Its Early History, Conceptualization, and Practice

A person reading the scholarly employee voice literature could easily conclude the subject did not exist before Albert Hirschman wrote Exit, Voice and Loyalty (1970). His book is repeatedly cited as the root stem of the field, with the implication no one before him had given serious consideration to the idea. A Google search on the term "voice" reveals in a matter of seconds, however, that here is a serious case of historical myopia. Yes, Hirschman deserves credit for being the first to develop a formal theory of voice, albeit limited to people in their role as consumers in product markets. Accordingly, Freeman and Medoff (1984) also deserve credit because they were the first to take Hirschman's theoretical ideas and apply them to employees in labor markets. Unacknowledged and unrecognized, however, is a long train of writing on employee voice that predates Hirschman and Freeman and Medoff by a century and more.

In this chapter I give a brief overview and synthesis of the early writing on employee voice. Part of the mission is to sketch a missing component in the history of thought, a discussion which I believe most readers will find interesting and useful in its own right. This historical analysis also has an instrumental purpose, however, which is to shape, inform, and critique the present-day research program on employee voice. For example, this review reveals that modern-day scholars have substantially re-invented a concept well-known and utilized many years earlier. More substantively, this early literature not only provides important insights regarding the definition, meaning, and conceptualization of employee voice but also indicates shortcomings in modern work on the subject. Finally, the early literature reveals an empirical pattern of employee voice noteworthy for its diverse organizational forms and breadth and depth of practice.

It is impossible to cover in one short chapter early voice literatures across multiple countries. This review, therefore, is largely limited to American experience and authors, although several writers based in Britain are selectively introduced. An advantage of the American case is a rich documentary record; a drawback is omission of important voice forms and developments in other countries (e.g., syndicats in France, works councils in Germany).

The Idea of Employee Voice

The employment relationship is a team form of production embedded in a capitalist market economy coordinated by a top-down authority structure. It became important in world history with the rise of capitalism and wage labor, decline of self-employed farmers and artisans, end of feudalism and slavery, and development of large-scale factories, mills and railroads. 
Put in this context, it seems strange that the employment relation has existed for hundreds of years and yet the concept and practice of employee voice has only attracted attention in the last thirty years or so (see, for example, Addison 2005; Brinsfield, Edwards, and Greenberg 2009; Morrison 2011; Holland, Pyman, Cooper, and Teicher 2011). Actually, the idea of employee voice goes back more than two centuries to the start of the Industrial Revolution.

Provided below are different perspectives on employee voice drawn from four distinct literature bases, with illustrative quotations. The voice term is italicized in each quotation to give it attention. Since the concept and definition of employee voice in the modern-day literature remains somewhat splintered and contested, I endeavor to inform this discussion and move it forward by supplementing these quotations at places with brief interpretative comment.

\section{Economics}

The first writers to use the voice term come from economics. The field was born with the publication Adam Smith's Wealth of Nations (1776/1937). In the book Smith specifically discusses the concept of employee voice. He states, "The laborer['s]... voice is little heard and less regarded [except] upon some particular occasion, when his clamour is animated" (pp. 396-97).

Several noteworthy features deserve highlight. We see, for example, that use of the voice term to connote the employee's act of speaking-up and expressing his or her mind goes back more than two hundred years. Although not explicitly stated by Smith, from the context of surrounding sentences one also sees that he envisions voice as including both individual and group expression. It appears that Smith also defines voice to include more than simple verbal communication, per the idea of "animated clamour." Smith further expresses a dichotomy between voice as communication (the message is heard) and influence (the employer takes action). Smith likewise suggests that voice as communication often fails to register with employers and is even less effective as influence. In an earlier chapter of the book, Smith sheds additional light on this matter by noting that the interests of employers and employees "are by no means the same" and "masters must generally have the advantage" (pp. 66-67). Thus, Smith can be read as suggesting that employers may be "hard of hearing" either because it serves their interests to ignore employee voice or they feel little inducement to act on it.

Another economist who uses the voice term is Karl Marx. He writes in Volume 1 of Capital (1867/1906), 
He [the employer], like all other buyers, seeks to get the greatest possible benefit out of the use-value of his commodity. Suddenly the voice of the laborer, which has been stifled in the storm and stress of the process of production, rises: The commodity I have sold to you differs... [for it] is the use of my labor-power...I will, like a sensible saving owner, husband my labor power [against] an unlimited extension of the working day... Hence is it that in the history of capitalist production, the determination of what is a working day, presents itself as the result of a struggle, a struggle between collective capital, i.e., the class of capitalists, and collective labor, i.e., the working class (pp. 257-59).

Like Smith, Marx indicates that the worker's voice is apt to go unheeded. However, Marx's use of the word "stifled" suggests employers actively discourage employee voice, in part because during the "storm and stress of production" they either have more pressing matters to deal with or regard voice as an unwanted intrusion. Marx also intensifies the divergence of interests between the employer and employee into a "struggle" and more sharply frames this struggle as diametrically opposed, class-based, and insoluble within the bounds of capitalism. Marx adds the idea that the worker and employer are in a bargaining contest over the terms and conditions of employment and the worker deliberately holds-back effort (labor power) as a bargaining chip and protective response. Finally, Marx emphasizes that workers use voice to not only advance their economic position but also safeguard their human capital from wear, tear and exploitation.

Another famous 19th century economist is John Stuart Mill. He states in his autobiography (Mill 1874),

I saw no more reason why women should be held in legal subjection to other people, than why men should be. I was certain that their interests required fully as much protection as those of men and were quite as little to obtain it without an equal voice in making the laws by which they are bound (p. 244).

Mill is here calling attention to the fact that the unequal treatment of women originates in part from a tilted regime of law and regulation - including discriminatory laws and regulations affecting women's participation, treatment, and reward in employment. Thus, he suggests that employee voice has to be broadly considered to include giving workers, whether women or other groups, some say and influence on rule-makers at two levels - managers in firms and legislators in national governments.

Trade Unions

A second literature base that used the voice term comes from trade unions and their leaders and supporters. Although trade unions in the USA go back to the start of the 19th 
century and considerably earlier in Britain, it was only in the latter part of the 1800 s that unions became permanently established and a national presence.

The voice term quickly became a standard part of the discourse about unions. In late 19th century America, for example, books and pamphlets appeared with titles such The Voice of Labor: Some Advice to Workingmen (Porter 1886) and The Voice of Labor, Containing Special Contributions by Leading Workingmen Throughout the United States (Jelley 1888). A number of trade union journals and newspapers also used the voice term in the title (e.g., The Miner's Voice; Wisconsin Voice of Labor) and in the 1920s the Chicago Federation of Labor started a radio station WCFL called "Voice of Labor" (Godfried 1997).

Proponents of trade unions used the voice term to explain and justify their mission and activities on economic, political and human rights terms. They also frequently joined the concept of voice with that of industrial democracy (Derber 1970; Lichtenstein and Harris 1993), as was influentially articulated by Sidney and Beatrice Webb (Industrial Democracy, 1897). As trade unionists saw it, competitive capitalism of that era forced workers to sell their labor as a commodity and, to get and keep jobs in an overstocked market, they had to accept poverty wages, twelve hour workdays, and firing without cause. Likewise, the common law of the employment relationship, based on the masterservant doctrine and sanctity of private property rights, put the employer in the position of an industrial monarch who had near-unlimited authority to govern, discipline, and terminate employees as he deemed appropriate. Accordingly, when workers are treated as commodities and industrial serfs, it is inevitable that they rebel when basic canons of social justice and human rights are violated. The mission of trade unions, therefore, is to use collective bargaining and political action to restore equality of bargaining power in labor markets, bring industrial democracy to the workplace, and protect and advance workers' human rights in industry.

Henry Demarest Lloyd (1893) in the USA captures these themes when he states, "it is the share of the majority [the nation's workers] to have no voice, to do the hardest work and feed on the crumbs of life... In a thousand trades labor is forced by compulsion stronger than that of the British stamp acts to sell labor to a ruler" (p. 7). He continues "Democracy must be progressive or die," "all must have a voice," and (quoting Abraham Lincoln), "A house divided against itself cannot stand" (p. 8).

One of organized labor's most articulate and well-known spokesmen in the late 1800s was John Mitchell , president of the United Mine Workers (USA). He states (Mitchell 1903), 
There is much lip service paid to the ennobling effect of labor...but it is the trade union, and the trade union alone, which translates these professions into actual deeds. The same man who...discourses eloquently upon the dignity of labor is unwilling that his employees shall have anything to say with regard to the conditions of their work...The working man...is the ultimate repository of power and the real producer of the wealth of the nation [yet] he is not considered worthy of a voice in the disposal of his time" (p. 158).

Even better known than Mitchell was Samuel Gompers, long-time AFL president. He wrote (Gompers 1920),

The synonyms for 'union' shop and 'non-union' shop respectively are 'democracy' and 'autocracy.' In the union shop the workers are free men... Employees in the non-union shop are like cogs in a machine. They have nothing to say as the conditions under which they will work, but must accept any wages, hours and working conditions that may be fixed arbitrarily by the employer. A non-union man who accepts employment in a union shop has the privilege of joining the union which has a voice... with employers (p. 2).

\section{Management}

Recognition of a distinct functional activity called management did not begin in the USA and Britain until the 1880s and did not blossom into a focused literature until after the turn of the century. A specialized branch of management devoted to personnel/employment took even longer to develop. In America, it first appeared in the early 1910s under the label employment management and then evolved into personnel management and industrial relations in the late 1910s (Kaufman 2008); in Britain it developed more slowly and was more narrowly framed as an industrial welfare function (Gospel 1992; Kaufman 2007). Since in this period personnel management and industrial relations covered overlapping but distinct participants and knowledge/subject domains, I deal with the former here and the latter in the next section.

From the 1880 s to the end of the 1910s the United States experienced a growing labor problem. Unions spread and became more militant, many strikes broke-out and a number were quite large and violent, companies experienced very high rates of employee turnover and disaffection, and to many people it appeared that class relations between capital and labor were slowly becoming more polarized. A major impetus behind the development of the modern practice of management, therefore, was to discover ways to re-unite employers and employees in order to promote harmony, cooperation, and higher firm performance. 
An employer who devoted considerable attention to improving relations between employers and employees was John D. Rockefeller, Jr. One of his family's businesses, the Colorado Fuel and Iron Company, was rocked in 1914 by a devastating strike - popularly known as the Ludlow Massacre, and this event spurred Rockefeller to investigate new approaches to labor management. Rockefeller's diagnosis of the problem was that labor-management conflict stems primarily from lack of communication, mutual understanding, and proactive resolution of frictions; these conditions, in turn, were aggravated by the loss of personal contact between employer and employee as industry evolved from small workshops to huge impersonal factories and mills. He explains (Rockefeller 1916),

Most of the misunderstanding between men is due to a lack of knowledge of each other. When men get together and talk over their differences candidly, much of the ground for dispute vanishes. In the days when industry was on a small scale, the employer came into direct contact with his employees, and the personal sympathy and understanding of each grew out o that contact and made the rough places smooth (pp. 13-14).

Rockefeller traveled to Colorado with labor advisor Mackenzie King and spent a number of days talking with managers and workers. He decided to create a representation plan with joint employer-employee committees in order to help rebuild lost communication and personal contact. On this he states,

The men in each mining camp were invited to choose, by secret ballot, representatives to meet with the executive officers of the company to discuss matters of mutual concern and consider means of more effective co-operation in maintaining fair and friendly relations. That was the beginning, merely the germ, of a plan [of employee representation] which has now been developed into a comprehensive 'Industrial Constitution.'... Some have spoken of it as establishing a 'Republic of Labor.' Certain it is that the plan gives every employee opportunity to voice his complaints and aspirations, and it neglects no occasion to bring the men and the managers together to talk over their common interests (pp. 18-19, 26).

Several points deserve notice. Although trade unionists were the first to frame employee voice as a matter of industrial democracy, by the mid-1910s managers also began to use various governance metaphors. Rockefeller, for example, speaks of "Republic of Labor" and "Industrial Constitution" while other management writers (e.g., Leitch 1919) called representation schemes "plans of industrial democracy." The managerial form of industrial democracy, however, is an employer-created "inside" form of employee voice rather than an independent "outside" form as with a trade union. Also noteworthy, Rockefeller illustrates the tendency of management writers to 
downplay structural sources of conflict, such as divergent interests, unequal bargaining power, and capitalist ownership of industry, and instead focus attention on strengthening a sense of common interests through improved communication and bilateral resolution of differences. Finally, Rockefeller also emphasizes that the shift from small workshops to large factories and mills requires a parallel shift from personal forms of employer-employee interaction and direct employee voice to organized coordination and indirect forms of voice and involvement.

Other corporate executives of this period also spoke about employee voice in unitarist and mutual gain terms. For example, in an article entitled "How We Brought Management and Men Together," Chief Operating Officer W.W Atterbury of the Pennsylvania Railroad says of the company's new representation plan (Atterbury 1924),

Summarized in one sentence, the gist of the Pennsylvania plan is this: To give employees an opportunity through employee representatives to have a voice in the management on all matters affecting our mutual welfare... The theory underlying our plan is simply that we are giving our employees a chance to see that only a prosperous company can pay good wages, that the company's success is their success, and its failure is their failure, and than men and management are merely two divisions of the same working forces (p. 42).

Although the use of the voice term was frequently associated with the movement to set up works councils and representation plans, it had a more general provenance in the managerial discourse of this period.

Frederick Taylor, for example, claims that his program of scientific management gives "workers in the end equal voice with the employer" (quoted in Hoxie 1916: 836). Taylor, however, conceives of voice not as ex ante communication and discussion but ex post influence through "arbitrament of science and fact" (ibid.). Voice, in his schema, is provided through the medium of neutral, fact-based engineering of workplace practices by scientists and technical experts.

Employers quickly discovered, however, that when they tried to install scientific management their workers strongly resisted the new program and sometimes went out on strike to stop it. One of Taylor's disciples, Robert Valentine, argued that the problem arose from Taylor's too-mechanical and elitist notion of voice. In an influential paper entitled "The Progressive Relation of Efficiency and Consent" (1915), Valentine asserted that scientific management is bound to fail unless it gives workers genuine voice and participation in the process since otherwise they feel the plan is forced on them and will refuse to cooperate. 
The marriage of scientific management with a human conception of the worker became the foundation for the new fields of employment management and personnel management in the 1910s in the USA. Employee voice, in turn, was regarded as essential to successful practice of this new approach to people management for reasons Valentine had outlined. Thus, two pioneers in employment management state (Bloomfield and Willets 1916),

This attention to the human problems has emphasized the need for the development of a science of employment and personnel management... so that some of the waste experienced by both employers and employees may be eliminated and the personnel function raised to its proper place in industrial management. It is highly important that, as this movement develops, the voice of the worker and the voice of the social agencies be prominently heard (p. viii).

By the end of World War I (WWI) the discussion of personnel management, works councils, and industrial democracy evolved into the new topic of workers' participation in management (Kaufman 2001). Here too employee voice was featured. For example, Benge (1920) observes, "Participation in management has sprung up from many causes...Some employers have felt it to be an easy way to combat unionism; others have had sufficient faith....to grant a voice in the conduct of the business" (p. 237).

Some management writers also discussed why employee voice, per Adam Smith's observation, is not more actively solicited and acted upon by employers. Lewisohn (1926) observes, for example, that managers find dealing with employee complaints and suggestions "tinged with an unpleasant emotional state, which makes the whole subject distasteful to them" (p. 566). Another states that many employers "never introduce it [representative voice] on the grounds that it infringes on the rights of the foremen, their all-necessary adjunct to the success of the business" (MacNamara 1920: 103). A third observes that many managers are "unwilling to relinquish the reputation of knowing it all" (Porter 1905: 219).

Industrial Relations

Industrial relations first emerged as a formal academic field of study and business practice area about 1920 in the USA (not until the late 1940s in Britain), although its roots extend to Britain and Germany and writers such as the Webbs and Brentano (Kaufman 2004). Personnel management, or what today is called human resource management, was specifically focused on the management side of the employment relationship, emphasized managerial objectives and practices, and among the more behavioral -oriented in the field drew significant input from psychology. A review of the 
personnel literature reveals that the closer to the psychology side one goes the less the employee voice concept is encountered.

Industrial relations, by way of contrast, was more broadly focused to cover all sides of the employment relationship, including managerial, labor, and societal interests, and took a more external/macro focus on markets, institutions, laws, and policy. Industrial relations was presented as an integration of employment perspectives and knowledge bases; in practice, although it contained a managerial component, the field's center of gravity was in political economy and law and gave greater weight than personnel management to progressive social reform and helping the worker underdog.

The divergence between personnel and industrial relations, along with attention to the concept of employee voice, is indicated in this passage by American labor economist William Leiserson. He states (Leiserson 1919),

In any plan or policy of labor management for industrial enterprises two sets of labor relations must be clearly distinguished. First, the personal relations which present the personnel management problems; and secondly, the economic collective relations which cover the problems of bargaining and democracy...The personal relations in industry cover such questions as hiring, selection, placement, training,...These questions...are not essentially controversial in nature; they do not involve conflicting interests and they have to be settled by good management and scientific experts... The second set of labor relations... has to do with the division of the product of industry, with the government or control of industry, with bargaining, wages, hours, unionism, and shop discipline. The return that workers should get for their labor,...the voice they should have in making disciplinary rules,... these are questions that present controversial issues which cannot be settled by technical experts. They are matters which require democratic discussion and about which a wide diversity of opinion will be permitted (pp. 8-9).

Leiserson goes to say,

Committees of employees may be used by the technical men who handle the personal relations in industry, but they are not the same kinds of organizations of employees that are needed to deal with the economic or governmental relations. The first can be permitted to offer to the management only advice and suggestions. The second must have a veto power on the acts of management and will sooner or later demand an equal voice in determining wages and hours and controlling discipline (p. 11).

We see here clear recognition that the employment relation contains several dichotomies -- integrative vs. distributive, administration vs. bargaining, individual vs. 
collective, managerial vs. democratic - and therefore requires different expressions and forms of employee voice.

The lead academic figure in American industrial relations was John Commons. He took a group of graduate students on a cross-country tour of thirty companies to study alternative forms of labor management and workforce governance. The case studies were published as a book with the title Industrial Government (1921). He summarizes their findings, stating: "From 10 to 25 per cent of American employers may be said to be so far ahead of the game that trade unions cannot reach them. Conditions are better, wages are better...The other 75 per cent to 90 per cent are backward... and only the big stick of unionism or legislation can bring them up" (p. 263).

As Commons saw it, all employees deserve a base-line of decent wages and hours, job security, opportunity for voice, status and dignity, and due process protection in dispute resolution. Where management voluntarily provides these, a trade union form of industrial government is not required. For example, he calls the nonunion system of labor management at the Ford Motor Company, "just old-fashioned industrial autocracy tempered by faith in human nature" (p. 24). Nonetheless, since Ford's labor practices were in the top 10-25 percent, Commons observes, "Why should there be any industrial democracy, grievance committee, or labor organizations, when nobody can be fired anyhow... and management always has a line on the foremen who have too much trouble?" (p. 25). He concludes, "The open shop [nonunion workplace] may be either a cloak to hide long hours, competitive wages, and voiceless workers, or it may be freedom for the management in furnishing reasonable hours and fair wages for manly workers" (p. 265). Where the former is the case, Commons argues that labor law and collective bargaining have to provide workers with an outside collective form of voice.

Another industrial relations writer of national prominence was Sumner Slichter. He notes a transformation took place in labor management philosophy and practice before and after World War I. Before the war, unemployment was extensive and employers could use the threat of discharge to coercively motivate and control workers (called the drive system); after the war, however, threat of discharge lost its power because unemployment was much lower and, hence, employers had to motivate and control workers by building up their morale and commitment through a positive program of good wages, job security, and fair treatment. Thus, one approach to industrial relations gains cooperation through negative coercion while the other gains it through positive inducement. With this in mind, Slichter (1919) states, "As the importance of labor's cooperation becomes more apparent, the more apparent will become the desirability of making labor an insider in industry with a corresponding voice in its direction (p.60). 
Slichter thus highlights an external contingency critical to effective employee voice - the level of unemployment - that most management writers neglect. Other industrial relations writers argued that voice is likely to remain under-supplied until labor law and trade unions give workers more power and insider's status. For example, Fitch (1920) argues,

The first noteworthy thing about the worker in his relation to industry is that he has no right to a voice concerning it. Often he succeeds in establishing such a right for himself, but he can get and keep such a right only by fighting for it... This means that he can have no voice in industry without organization, and the whole history of the American trade union movement shows that the right to organize is also a thing for which he must fight" (p. 2).

Early Forms of Employee Voice

The idea of employee voice, at least in America, was evidently well-known and frequently used a century and more ago. So, what about the practice of voice? Was it also widespread and, if so, how was employee voice organized and provided?

The historical record suggests employee voice options and coverage were quite limited in the USA before World War I. As described below, many employers actively discouraged voice and, thus, a large swath of industry could accurately be described as falling in the "No Voice" category. Workers who had some kind of formal voice option were typically members of trade unions. Most AFL unions, however, included only workers from skilled trades and crafts and, hence, the mass of unskilled and semi-skilled manual workers were mostly on their own. After WWI, nonunion voice options substantially expanded with the birth of the personnel/industrial relations function, the emergence of professional management, the development of the welfare capitalism movement, and the shift from an external to internal labor market strategy by many companies.

As Hirschman posits, an alternative to voice is exit and workers through the WWI era used the exit option in droves. Turnover rates in American industry in the 1910s - when the first companies started to keep records on the matter - were phenomenally high. Marcus Alexander (1916) did the first quantitative study of turnover and found the number of new hires in twelve plants was roughly six and one-half times larger than needed to fill the growth in jobs. A movement quickly developed to stabilize employment; out of this proliferated, in turn, formal internal labor markets and organized voice through employee representation. 
Workers also used other tactics besides exit to signal employers about their dissatisfactions, grievances, and unmet demands. Many strikes in that era, for example, were not led by unions but occurred as short and mostly unplanned walk-outs by unorganized workers in a department or plant. Some of these strikes mushroomed into hugely destructive conflagrations, such as at Pullman in 1894 with thirty people dead and eighty million dollars of railroad property destroyed. Here are examples of Smith's voice as animated clamour. Other signals included absenteeism (up to ten percent on Mondays at Ford Motor), deliberately working slow (Frederick Taylor's much hated "soldiering"), a bad and belligerent attitude (called "kicking").

Presented below is a brief synopsis of alternative voice forms in American industry prior to the New Deal. They are arranged along a spectrum from low to high in terms of extent of organizational breadth/depth, formalization, and influence, starting with No Voice and ending with Workers' Control.

No Voice

Many companies, particularly before WWI, not only did not have a voice option but rejected and perhaps actively discouraged it. The employer adopted the role of army general, absolute monarch, or master of the household - a person with great authority whose orders are to be obeyed without question or talk-back and who uses harsh punishment to maintain compliance and control.

A flavor of the No Voice style of workplace is given in this remembrance by Don Lescohier. He worked in a factory before WWI and recalls (Lescohier 1960),

"Ordinarily a man hired in this process did not know what his pay would be until he got his wages on payday. If you asked the foremen that question when you were hired you would, ordinarily, be shown the gate. Complete submission of unorganized workers to the company was the expectation at the Detroit Stove Works. Like hundreds of other common laborers I had heard the foreman say to me: 'Put on your coat,' which meant that you were fired. You did as he said" (p. 32).

Also instructive is this remembrance by Daniel Willard. As a teenager he started out on a railroad track gang and then worked his way up to become president of the Baltimore \& Ohio Railroad. He recalls (Willard 1927),

I was young and enthusiastic, and I saw something that seemed to me ought to be done, and it wasn't being done, so I thought the thing to do was to go and tell the officer, the master mechanic or whatever his title was, what I had in mind, and he said, 'Sonny, you had better keep still; when they want your advice they will ask you for it, and I wouldn't volunteer any advice.' And then I learned that 
there was a definite thought in the minds of the all the men, that if they wanted to get along with management they had better not make suggestions" (p. 263).

Individual Voice

If voice was an option for workers, it first started with informal one-on-one voice in the form of individual discussion, usually on the shop floor with a gang boss or foreman but sometimes higher up such as the business owner or department head. For example, one writer (Roland 1896) visited six companies and found at most "an absence of a fixed method and a general policy of individual treatment" (p. 395) with communication and bilateral relations maintained by "perpetual and everywhere personal influence" of the owner and lower-level managers (p. 410).

Other open shop employers gave formal expression to their voice policy. Most often it was called the open door. An open door company was the U.S. Steel Corporation. Its president, Elbert Gary, said (quoted in Levenstein 1962),

Any employee... is at liberty at all times to present to the respective foremen and, if desired, the higher appointees and officials, all questions involving the interests and welfare of both employee and employer for discussion and disposition. In this way fair and satisfactory adjustments are made (p. 61).

Gary opposed collective forms of nonunion voice, such as shop committees, because they compromised managerial control and could be "the beginning of a full and thorough unionization of the industry" (ibid., p. 62)

Henry Ford had an organized grievance resolution committee in the late 1910s but later abandoned it in favor of individual dealing and the open door. On the open door he states (Ford 1924),

Any workman can go to anybody, and so established has become this custom, that a foreman does not get sore if a workman goes over him and directly to the head of the factory. The workman rarely ever does so, because a foreman knows as well as he knows his own name that if he has been unjust it will be very quickly found out, and he shall no longer be a foreman. One of the things we will not tolerate is injustice. (p. 92).

In practice, the open door at Ford Motor progressively atrophied over the 1920s, as did all forms of voice (conversing with workmates was forbidden during work hours) as Henry Ford turned toward a lean and mean labor strategy. Other companies, however, walked the talk on the open door and close personal communication between manager and worker. 
An example is the Endicott-Johnson Company, the nation's largest shoe manufacturer. Its president, George Johnson, made unity of interest a strategic business objective. To achieve it, Johnson went to great lengths to create a family culture where workers felt materially and emotionally invested in the success of the company. This close connection was fostered by devices such as job security, generous wages, and profitsharing; also key was giving employees voice through close personal contact and attention to their needs and problems. Thus, Johnson framed successful voice as resting on principles of "Personal Contact," "Putting Yourself in the Other Person's Shoes," and the "Square Deal" (Zahavi 1988: 40). Toward this end, Johnson spent hours walking though the company's plants to talk with workers, many of whom he knew by name. His office was also regularly open to employees and a steady stream came in to talk about problems and special needs, many of which Johnson personally took action on. Part of the return on this investment was that the workers remained loyal to the company and did not unionize during the 1930s (ibid.).

Small-Scale Collective Voice

Still within the nonunion part of industry but next up the rung of employee voice are employers who formed various kinds of small-scale, decentralized and informally organized teams and committees. These groups were the beginning of indirect (representative) forms of employee voice.

Here is a brief synopsis of these types of committees and voice forms in the USA as gleaned from periodicals and reports from this era. They reveal a mix of voice and participation functions.

Welfare committees (Bureau of Labor Statistics 1919). An industrial welfare movement developed after 1900 in which employers provided new amenities and benefits for workers, such as cafeterias, savings plans, athletic programs, washroom facilities, and recreation halls. In a number of cases they gave groups of employees an opportunity to help create and operate the new programs. A report notes, for example, that some firms "allow their employees to manage the lunch room... The employees quite frequently have a voice in the management of the club rooms or houses... The administration of the benefit [thrift] associations is in most cases either mutual or in the hands of the employees" (p. 121).

Safety committees (Williams 1919). A writer states, "The function of the Workmen's Inspection Committee is to inspect the shop, or one department thereof, for safety, and make recommendations for the removal of hazards...The Workmen's Safety Committee is, as far as I know, the first recognition in this country on a large scale of the 
principle that it is advantageous to give rand and file workmen a voice in determining shop conditions" (p. 95).

Piece-rate and profit-sharing committees (Tead 1917; Farnham 1917). Employers also created employee voice committees to help administer variable pay compensation programs, such as with piece rates and profit-sharing, in order to promote trust and transparency in the determination of pay-outs and ensure that variable pay is a source of increased mutuality and not conflict. Tead (1917) notes, for example, "Price committees, perforce, exist already in industries where piece rates have constantly to be set" (p. 253) while Farnham (1917) states, "an opportunity to share in the profits aroused among the employees such an interest in the company's affairs that they felt they should have a share in the management and determination of the policy" (p. 765).

Grievance committees (Watkins 1922). This author describes a four step process for resolution of grievances, starting with a branch committee composed of equal number of management and employee members. Unresolved grievances move up to committees at the department and firm level and then, if still unresolved, are submitted to an arbitrator (p. 468).

Expense committee (Morgan 1925). A temporary committee of four people assigned to review all aspects of operations and policy and make recommendations to senior management. The company president notes that resistance from lower-level managers and supervisors is "where an economy committee is bound to strike its first snag" (p. 742) since they feel threatened by loss of authority and exposure to criticism.

Special Project Team (Iron Age, "Improving the Personnel," May 18, 1916). The general manager of the Fore River Shipbuilding company relates, "It was recently determined to see what could be done to improve the quality of the employees and to increase efficiency... A committee of employees was carefully selected and sent to inspect fifteen large manufacturing plants,... the object of the committee's visits being to obtain as much information as possible relative to both personnel and plant betterment" (p. 1198).

Shop Committees, Works Councils, and Employee Representation Plans

In America the highest level of formal collective voice in nonunion establishments before the New Deal was in the form of shop committees, works councils, and employee representation plans (ERPs). These groups provided a permanent basis for voice that included workers across a facility, plant, or company. A few representation plans included employee representatives on the board of directors; some companies used the plans as a substitute for a personnel department. 
Employee representation developed into a large and influential industrial relations practice after WWI, encompassing a decade later more than 800 plans and covering roughly 1.5 million workers (Nelson 1982). The American movement was partly employers' attempt to set-up a nonunion version of the Whitley Councils introduced in Britain after WWI (Gospel 1992). Balderston (1935) assembled case studies of twentyfive of the most advanced employee relations programs in the USA. Twenty companies were nonunion and fourteen of these had some form of ERP. Most of the corporate leaders of the welfare capitalism movement, such as DuPont, General Electric, Goodyear, International Harvester, Standard Oil of New Jersey, and Westinghouse, had ERPs.

All ERPs were created and operated by employers; otherwise their specific characteristics and functions varied widely. Some companies set them up as a bilateral communication channel, others billed them, respectively, as serving an advisory and consultation function, an organized method of employee participation in management, a form of industrial self-government (industrial democracy), or a nonunion form of collective bargaining. Typically workers voted for representatives in secret ballot elections and the representatives then interfaced with first-level supervisors on an informal day-to-day basis and with upper level management in periodic formal meetings. The advanced ERPs had written constitutions, monthly meetings, discussed all aspects of operational and personnel activities, paid employee representatives for council duties, and created a formal process for dispute resolution. The companies that set up ERPs as an alternative form of collective bargaining frequently entered into written contracts with the employees' organization. By most accounts, the ERPs on balance had a discernible influence in resolving frictions, improving work conditions, promoting mutual understanding, and tempering discipline and discharge (Kaufman 2000); their effect on wages, hours, and other economic matters were less evident but on balance also positive (Farris 1997; Pencavel 2003).

With the onset of economic depression in late 1929, some ERPs were dropped and others became inactive -- either because the plans fell victim to deep cost-cutting or no longer seemed needed in an environment of mass layoffs and unemployment. The true believers in representation, however, not only kept the plans going but utilized them to help co-manage layoffs, wage cuts, work-sharing, and relief activities. After coming to office in early 1933, President Roosevelt pushed forward a New Deal economic recovery program that encouraged collective bargaining as a way to raise wages and purchasing power. Several thousand companies responded by quickly setting up ERPs as a nonunion form of collective bargaining. Within several years ERP membership mushroomed to 2.5 million (Nelson 1982). This new group of ERPs became quite controversial because they 
were seen as a crass and mostly illegitimate union avoidance tactic and also a threat to the goals of the president's economic recovery program (Kaufman 2000).

Abetted by widespread public disillusionment with employers and competitive markets, Congress enacted the National Labor Relations Act (NLRA, or Wagner Act) in 1935 which declared all forms of nonunion collective dealing with employees over a term or condition of employment -- even if only bilateral discussion in a small-scale committee an illegal unfair labor practice. Hence, many forms of collective worker voice disappeared, in some cases replaced by an independent labor union or a nonunion committee focused only on production related matters (Jacoby 2000).

One of the earliest ERPs, established about 1900, was at William Filene and Sons, a Boston retail department store (Kaufman 2010: 58-63). It was called the Filene's Cooperative Association (FCA). The FCA was one component of a pioneering set of advanced human resource practices installed by the company, including an employment management department, profit-sharing plan, and peer review board of arbitration. The author of a case study of the company observes, "The Filene's Co-operative Association, if not the original plan of employee participation in management, was among the earlier of such plans (La Dame 1930: 119). She reproduces the written charter of the FCA and its states as the organization's first purpose, "To give its members a voice in their [industrial] government" (p. 121).

The company selected by Balderston (1935) as having the best employee relations program in the United States was Leeds and Northrup, a manufacturer of scientific instruments and measuring devices. Unusual for a company of that period, it gave all new employees a written employees' handbook The table of contents lists twenty-six items, including wages, hours, working conditions, overtime, vacations, lay-off and discharge, lunch room, and attendance bonus. One of the twenty-six is an ERP. The voice plan's relative importance is indicated by the fact it is listed as the second item in the table of contents only behind the executive committee. The handbook states that the association's objective is "to furnish an organization in which the employees may cooperate for their mutual welfare and through which they may work with the management in matters that pertain to their interests." (p. 3). The workers' committee elected a "board of councilors" which met with the executive committee once a month; most of the association's work, however, was done through twelve sub-committees (including an employees-only grievance appeal board).

Independent Labor Unions 
The next gradation in employee voice is the independent labor union. In that period most unions were organized along craft and occupational lines and hence were commonly known as trade unions. The unions portrayed themselves as the organized form of voice for American workers, per Gompers' statement that the labor movement "voices the aims and hopes of the toiling masses" (Gompers 1953: 32). Trade union density in the USA started out in the early 1900 s at less than five percent, rose slightly above ten percent at the eve of WWI, surged to nearly 20 percent by the end of the 1910s, slowly shrank back to near ten percent in the early 1930s, and then surged past the twenty percent level during the New Deal period of the 1930s.

Trade unionists were highly critical of ERPs which they contemptuously called company unions. AFL president William Green (1925) attributed the company union to employers' "desire for autocratic control and managerial domination. They seek to maintain the form of collective bargaining without its substance or its spirit of independence" (p. 244). Robert Dunn (1926) offered these more pointed critiques of ERPs:

Many of the plans lie more or less dormant when there are no strikes on the horizon, but in time of industrial disturbance they are revived and dressed up to fool the worker again and keep him away from the real trade union (p. 15).

[D]elegates...meet to discuss baseball, bowling, picnics and banquets. But never [do] they at any time take up any matter that is of vital interest to the workers, such as wages and hours of labor (p. 33).

Any worker who is not close to the company has no chance of getting elected...Why don't the workers take up their grievances with their 'ward representative'?... The answer is simple: If he did he ...would be dropped from the payroll the next day (p. 38).

When the time came to cut wages, the machinery was at hand with which to do this expeditiously and peacefully (p. 51).

From the trade union perspective, most of the issues of vital concern to workers, such as wages, hours, and job security, inevitably create a conflict of interest between the employer and employee and thus have a significant element of win-lose. Further, employers are typically in the superior power position since they control who gets the jobs and can thus use the threat of termination to keep workers silent and submissive. In most cases, therefore, workers can only get meaningful voice when they are part of an independent labor union since the workers elect their own representatives, the union's leaders are free to speak-up and make demands, and the union has bargaining power through the strike threat and other sanctions to induce the company to make concessions. Union voice is also more effective because it extends common wages 
across all firms in the market and takes labor cost out of competition; ERPs, on the other hand, have no ability to create or protect minimum industry labor standards.

When unionism came to the steel industry in the mid-1930s, a magazine article described the transformation in voice terms when it used the title "A Man Can Talk in Homestead" (Fitch 1936). Similarly, unionism came to the apparel industry in the late 1910 s and the industry went from mostly nonunion to 90 percent organized. An observer notes (Chenery 1920),

The clothing industry, competitive beyond most of the other basic industries, left individual workers at the mercy of the autocratic government of hundreds of employers, themselves driven by the sharpness of the competition of trade... Six years ago less than 15 per cent of the garment workers earned as much as $\$ 20$ a week... approximately the lowest sum sufficient... for the humble maintenance of a family of five. Last year in New York four-fifths of the workers earned between thirty-five and fifty-five dollars a week... [Also], the worker had few rights which the employer had to respect. That too has gone. Every shop where the union is effective has its own leader. In the larger markets judicial and legislative machinery representative both of workers and of employers has been established...The clothing makers have citizenship in industry. They have the dignity, the self-assurance, that arises from knowledge of the solid bulwarks of their liberties" (p. 273).

The union just cited, the Amalgamated Clothing Workers of America, was unusual at this time because it entered into an official program of labor-management cooperation with employers in which the union worked with the companies to improve productivity and cost control. Several other American unions also adopted innovative labor-management cooperation programs, the most famous case being on the B\&O Railroad with the International Association of Machinists (Lauck 1926; Willard 1927).

The complaint of most employers, however, was that union voice is too focused on conducting a battle to win a larger slice of the economic pie for workers and not interested enough in cooperating with companies to grow the economic pie. A person observed on this matter (Seager 1920),

The introduction of an outside representative means at once emphasis on the conflicting interests of employer and employee. Disagreements are no longer analogous to disputes within the family in which both sides remain conscious of and are restrained by the common family interests. The trade or labor official has little or no concern with the business success of the plant in which the dispute has arisen. His primary concern is for the success of the union which he represents... and he is, therefore, anxious to obtain higher wages or more favorable working conditions... As found in most industries in the United States, 
the psychology of collective bargaining through shop committees is predominantly cooperative; that of collective bargaining through trade or labor union officials predominantly contentious" (p. 334).

He suggests that one solution to this problem is to conceive of trade unions and ERPs not as substitutes but complements (also Douglas 1921). That is, unions perform the distributive wage- fixing function at the industry level while ERPs perform the integrative cooperation-promoting role at the plant level. This suggestion never gained traction in the USA but was implemented in Germany with a combination of industry collective bargaining and plant level works councils.

\section{Workers' Control}

Opposite the No Employee Voice end of the spectrum is some variant of Workers' Control (No Management Voice). It was never more than a fringe movement in the USA (more so in France and some other countries) but deserves mention to round out the story.

The idea of workers' control goes back to early 19th century anarchist, communitarian, and syndicalist movements associated with people such as Owen, Fourier, and Proudhon. Robert Owen, for example, established a short-lived communitarian experiment at New Harmony, Indiana with a large measure of worker self-management. Later in the 19th century, workers' control became associated with workers' cooperatives as espoused by the Knights of Labor and other reform groups and, also, various versions of state socialism as espoused by Marx, Debs, DeLeon, and other radicals (Derber 1970).

Most of these versions of workers' control faded away by the 1920s. Some exceptions nonetheless remained. For example, workers cooperatives in the plywood industry were set up in the Pacific Northwest and still operate (Pencavel 2001). Most discussed, however, were companies such as the Duchess Bleacheries and Columbia Conserve Company. Lauck (1926) called the latter, "the most complete and perfect illustration of direct industrial democracy which exists today" (p. 286).

The company employed about one hundred people. Originally privately owned, the principal stockholder put all the shares into a trust under control of the Board of Directors and a Factory Council. The Board was composed entirely of employees, including managers, and its members were elected by workers in town hall meetings. The Board, acting on behalf of the employees, made all financial, operating, and personnel decisions. Thus, the workers chose the chief executive and top-level 
managers, approved capital investment expenditures, set hours of operation, and approved all salaries and wages. The company survived until 1953.

\section{Conclusion}

As this survey indicates, employee voice was a concept frequently discussed and practiced in early twentieth century American industry (the historical record in other countries is a topic needing research). Both the conceptualization and implementation were in important respects roughly formed relative to current standards. Nonetheless, attention to this historical experience with voice also yields important ideas and insights that people today can build on for new and improved theory and practice. This survey, for example, highlights the cross-disciplinary nature of the employee voice concept; the different dimensions of voice (e.g., communication vs. influence, individual vs. collective, managerial vs. industrial democracy, distributive vs. integrative), and the broad spectrum of voice forms coexistent in the economy. Although research on employee voice has considerably advanced since the pioneering studies of Hirschman (1970) and Freeman and Medoff (1984), this survey also indicates a distressing penchant among modern scholars to ignore contributions of our forebears, claim credit for rediscovering or dressing-up old ideas and distinctions, take a too narrow and scholastic perspective on a complex and multi-faceted reality, and neglect the rich diversity of voice forms of an earlier era and the lessons they provide for modern practice and policy.

References

Addison, John. 2005. "The determinants of firm performance: unions, works councils, and employee involvement/high performance work practices," Scottish Journal of Political Economy, 52 (3), 406-50.

Alexander, Marcus. 1916. Hiring and firing: its economic waste and how to avoid it', The Annals of the Academy of Political and social Science 65 (May), 128-44.

Atterbury, W. 1924. 'How we brought management and worker together', System 45 (January):

42-45.

Balderston, C. Canby. 1935. Executive Guidance of Industrial Relations. Philadelphia: University of Pennsylvania Press. 
Benge, Eugene. 1920. Standard Practice in Personnel Work. New York, NY: Wilson.

Bloomfield. Meyer, and Joseph Willits. 1916. 'Forward', The Annals of the American Academy of Political and Social Science 65 (May), vii-viii.

Brinsfield, Chad, Edwards, Marissa, and Jerald Greenberg. 2009. 'Voice and silence in organizations: historical review and current conceptualizations.' In J. Greenberg and M. Edwards (eds.), Voice and Silence in Organizations, pp. 3-33. Bingley, UK: Emerald.

Bureau of Labor Statistics, United States Department of Labor. 1919. Welfare Work for Employees in Industrial Establishments in the United States. Bulletin 250. Washington, DC: Government Printing Office.

Chenery, William. 1920. 'The vanguard of labor', The 'Survey (May 22), 273-75.

Commons, John. 1921. Industrial Government. New York: Macmillan.

Derber, Milton. 1970. The American Idea of Industrial Democracy. Champaign-Urbana, IL: University of Illinois.

Douglas, Paul. 1921. Shop committees: substitute for, or supplement to, trade unions?' Journal of Political Economy 29 (2), 88-107.

Dunn, Robert. 1926. American Company Unions. Washington: Trade Union Educational League.

Fairris, David. 1997. Shopfloor Matters: Labor-Management Relations in Twentieth-Century American Manufacturing. London: Routledge.

Fitch, John. 1920. "The Human factor in Industry." Address before the Massachusetts Conference of Social Work. John Fitch papers, Box 1, Folder 8. Madison: State Historical Society of Wisconsin.

1936. 'A man can talk in Homestead', Survey Graphic (February), 71-6, 118-19.

Ford, Henry. 1924. My Life and Work. Garden City, NY: Doubleday.

Freeman, Richard, and James Medoff. 1984. What Do Unions Do? New York: Basic Books. 
Gompers, Samuel. 1920. The Union Shop and Its Antithesis. Washington: American Federation of Labor.

1953. The American Labor Movement. Washington: Allied Printing.

Godfried, Nathan. 1997. WCFL, Chicago's Voice of Labor, 1926-1978. Urbana, IL: University of Illinois Press.

Gospel, Howard. 1992. Markets, Firms, and the Management of Labor in Modern Britain. Cambridge: Cambridge University Press.

Green, William. 1925. Address by William Green. Bulletin of the Taylor Society 10(December): 242-46.

Hirschman, Albert. 1970. Exit, Voice, and Loyalty: Responses to Declines in Firms, Organizations, and Nations. Cambridge, MA: Harvard University Press.

Holland, Peter, Pyman, Amanda, Cooper, Brian, and Julian Teicher. 2011. Employee voice and job satisfaction in Australia: the centrality of direct voice', Human Resource Management 50 (1), 95-111.

Hotchkiss, Willard. 1920. "Participation in Management - Discussion." American Economic Review 19 (March Supplement): 110-15.

Hoxie, Robert. 1916. 'Scientific management and labor welfare', Journal of Political Economy 29 (9), 833-54.

Jacoby, Sanford. 2000. 'A road not taken: independent local unions in the United States since 1935.' In B. Kaufman and D. Taras (eds.), Nonunion Employee Representation: History, Contemporary Practice, and Policy, pp. 96-120. Armonk: M.E. Sharpe.

Jelley, S.M. 1888. The Voice of Labor: Containing Special Contributions by Leading workingmen throughout the United States. Philadelphia: Smith.

Kaufman, Bruce. 2000. 'Accomplishments and shortcomings of nonunion employee representation in the pre-Wagner act years: a reassessment.' In B. Kaufman and D. Taras (eds.), Nonunion Employee Representation: History, Contemporary Practice, and Policy, pp. 21-60. Armonk: M.E. Sharpe.

. 2001. 'The theory and practice of strategic HRM and participative management: antecedents in early industrial relations,' Human Resource management Review 11 (4): 505-34.

2007. 'The development of HRM in historical and international perspective.' In P. Boxall and J. Purcell (eds.), Oxford Handbook of Human Resource Management, pp. 19-47. Oxford: Oxford University Press. 
2008. Managing the Human Factor: The Early Years of Human Resource Management in American Industry. Ithaca, NY: Cornell University Press.

2010. Hired Hands or Human Resources: Case Studies of HRM Programs and Practices in Early American Industry. Ithaca, NY: Cornell University Press.

La Dame, Mary. 1930. The Filene Store: A Study of Employees' Relations to Management in a Retail Store. New York, NY: Russell Sage Foundation.

Leiserson, William. 1919. Employment Management, Employee Representation, and Industrial Democracy. Washington, DC: U.S Department of Labor Working Conditions Series.

Leitch, John. 1919. Man-to-Man. The Story of Industrial Democracy. New York, NY: Forbres.

Levenstein, Harvey. 1962. The Labor Policy of the United States Steel Corporation 1920-1927. Master's of Science Thesis. Madison, WI: University of Wisconsin.

Lewisohn, Sam. 1926. 'Management: a behavior problem', Industrial Management, 56 (September), 565-68.

Lichtenstein, Nelson, and Howell Harris. 1993. Industrial Democracy in American: The Ambiguous Promise. New York: Cambridge University Press.

Litchfield, Paul. 1920. "The Industrial Representation Plan in the Akron Factories of the Goodyear Tire and Rubber Company," Annals of the American Academy of Political and Social Science, 90: 27-31.

Lloyd, Henry. 1893. The Safety of the Future Lies with Organized Labor. Washington: American Federation of Labor.

MacNamara, M. 1920. 'Shop Committee and the Foreman,' Industrial Management (August), 102-103.

Marx, Karl. 1867/1906. Capital: A Critique of Political Economy, Vol. 1. New York: Modern Library.

Merritt, Walter. 1920. "Employee Representation as a Step toward Industrial Democracy," Annals of the American Academy of Political and Social Science, 90: 39-44.

Mill, John Stuart. 1874. Autobiography. New York: Holt.

Mitchell, John. 1903. Organized Labor, Its Problems, Purposes, and Ideals and the Present and Future of American Wage Earners. Philadelphia, PA: American Book and Bible House.

Morgan, H. 1925. 'Saving \$1,000 Every Business Day', System (June), 741-46. 
Morrison, Elizabeth. 2011. "Employee Voice Behavior: Integration and Directions for Future Research, Academy of Management Annals 4: 373-412.

Nelson, Daniel. 1982. The company union movement, 1900-1937. Business History Review 8: 335-57.

Pencavel, John. 2001. Worker Participation: Lessons from the Worker Co-ops of the Pacific Northwest. New York, NY: Russell Sage Foundation. 2003. 'Company unions, wages, and work hours'. In D. Lewin and B. Kaufman (eds.), Advances in Industrial and Labor Relations, Vol. 12, pp. 7-38. Greenwich, CT: JAI Press.

Porter, H. 1905. 'The suggestion system', Cassier's Magazine (July), 218-22.

Porter, Robert. 1886. The Voice of Labor: Some Advice to Workingmen. New York: Ogilvie.

Rockefeller, John D., Jr. 1916. The Colorado Industrial Plan. New York: The Author.

Roland, Henry. 1896. 'Six Examples of Successful Shop Management', Engineering Magazine 12 (October), 69-85.

Seager, Henry. 1920. 'Needs of industry versus demands of organized labor', The Survey (January 3), 333-37.

Slichter, Sumner. 1919. "Industrial Morale," Quarterly Journal of Economics 35 (November): 3660.

Smith, Adam. 1776/1937. An Inquiry into the Nature and Causes of the Wealth of Nations. New York: Modern Library.

Tead, Ordway. 1917. 'Employees' organizations and their helpful uses', Industrial Management (November), 249-56.

Valentine, Robert. 1915. 'The progressive relation between efficiency and consent', Bulletin of the Taylor Society (November), 3-7.

Watkins, Gordon. 1922. An Introduction to the Study of Labor Problems. New York, NY: Thomas Crowell.

Webb, Sidney, and Beatrice Webb. 1897. Industrial Democracy. London: Longmans, Green.

Willard, Daniel. 1927. "The New Executive Viewpoint on Labor Relations" Industrial Management 73 (5): 260-63.

Williams, Sidney. 1919. 'Safety', Proceedings of the First Annual Convention, National Association of Employment Managers, pp. 92-97. 
Zahavi, Gerald. 1988. Workers, Managers, and Welfare Capitalism: The Shoeworkers and Tanners of Endicott Johnson, 1890-1950. Urbana, IL: University of Illinois Press. 